\title{
Follicle development, endocrine profiles and ovulation rate in adult Merino ewes: effects of early nutrition (pre- and post-natal) and supplementation with lupin grain
}

\author{
C Viñoles ${ }^{1,2}$, B L Paganoni ${ }^{1,5}$, K P McNatty ${ }^{3}$, D A Heath ${ }^{3}$, A N Thompson ${ }^{4,5,6}$, K M M Glover ${ }^{1}$,
} J T B Milton ${ }^{1}$ and G B Martin ${ }^{1,7}$

${ }^{1}$ Faculty of Natural and Agricultural Sciences, UWA Institute of Agriculture, University of Western Australia, Crawley, Western Australia 6009, Australia, ${ }^{2}$ Programa Nacional de Carne y Lana, Instituto Nacional de Investigación Agropecuaria, Ruta 5, km 386, Tacuarembó, Uruguay, ${ }^{3}$ Victoria University of Wellington, Wellington, New Zealand, ${ }^{4}$ Department of Primary Industries, Hamilton, Victoria 3300, Australia, ${ }^{5}$ Department of Agriculture and Food Western Australia, South Perth, Western Australia 6151, Australia, ${ }^{6}$ School of Veterinary Biology and Biomedical Sciences, Murdoch University, Murdoch, Western Australia 6150, Australia and ${ }^{7}$ Nuffield Department of Obstetrics and Gynaecology, University of Oxford, Oxford OX3 9DU, UK

Correspondence should be addressed to C Viñoles at Programa Nacional de Carne y Lana, Instituto Nacional de Investigación Agropecuaria; Email: cvinoles@adinet.com.uy

\begin{abstract}
In adult ewes, we tested whether ovarian function, including the response to short-term supplementation, was affected by the nutrition of their mothers during the pre-/post-natal period. A $2 \times 2$ factorial design was used with nutrition in early life (low or high) and a 6-day supplement (with or without) as factors. All ewes received three prostaglandin (PG) injections 7 days apart, and the supplement (lupin grain) was fed for 6 days from 2 days after the second until the third PG injection. We measured reproductive and metabolic hormones, studied follicle dynamics (ultrasonography), and evaluated granulosa cell numbers, aromatase activity and oestradiol ( $\left.E_{2}\right)$ concentrations in follicular fluid in healthy follicles at days 3 and 7 of supplementation. Ovulation rate was increased by $25 \%$ by exposure to high pre-/post-natal nutrition (1.5 vs 1.2; $P<0.05)$, in association with a small decrease in FSH concentrations $(P=0.06)$ and a small increase in insulin concentrations $(P=0.07)$. The number of healthy antral follicles was not affected. Acute supplementation increased the number of granulosa cells (3.7 \pm 0.2 vs $3.0 \pm 0.2$ million; $P<0.05)$ in the largest follicle, and the circulating concentrations of $E_{2}(4.6 \pm 0.3 \mathrm{vs} 3.9 \pm 0.3 \mathrm{pmol} / \mathrm{l} ;$ $P<0.05)$ and glucose $(3.4 \pm 0.03$ vs $3.3 \pm 0.03 \mathrm{mmol} / \mathrm{l} ; \boldsymbol{P}<0.01)$. Both early life nutrition and acute supplementation appear to affect ovulation rate through changes in glucose-insulin homoeostasis that alter follicular responsiveness to $\mathrm{FSH}$ and therefore $\mathrm{E}_{2}-\mathrm{FSH}$ balance. Reproduction (2014) 147 101-110
\end{abstract}

\section{Introduction}

In sheep genotypes such as the Merino, ovulation rate and fecundity are limited by nutrition and genetic background (Kleemann \& Walker 2005). Thus, ovulation rate can be increased by short-term supplementation with lupins, a legume grain with high contents of metabolisable energy (ME) and protein that can be safely fed as an acute supplement in large amounts because it contains low concentrations of fermentable starch (White et al. 2007). However, responses to shortterm lupin supplementation are variable and largely dependent on the ovarian population of antral follicles (Gherardi \& Lindsay 1982, Leury et al. 1990, Nottle et al. 1997, Viñoles et al. 2010b). In ewes, the population of antral follicles is affected by several factors, including genotype and body condition (Tassell et al. 1983,
Viñoles et al. 1999), and perhaps the perinatal nutritional history of their mother.

In sheep, low levels of maternal nutrition reduce the ovulation rate and prolificacy of their female offspring (Gunn et al. 1995, Rae et al. 2002). In cattle, a low level of nutrition during pregnancy decreases the numbers of antral follicles in the offspring, an effect that appears to explain their lifetime reproductive performance (Evans et al. 2010). It has long been known that undernutrition from conception to day 110 of pregnancy delays foetal follicle development in sheep (Rae et al. 2001), but longterm effects on the population of antral follicles in adulthood have not been studied. Importantly, in addressing this issue, it is essential to evaluate the functional status of the follicles, because only non-atretic follicles can respond to changes in nutrition. Ultrasonography can determine the growth trajectory of follicles 
but not their functional status, so we need to dissect and biochemically assess follicles at specific stages of the follicular wave (review Scaramuzzi et al. (2011)).

Short-term feed supplements such as corn grain plus soybean meal, glucose infusion and lupin grain evoke changes in the concentrations of metabolic hormones, with the peak of the response observed 3 days after the start of the supplement, in association with an increase in the number of antral follicles selected into the ovulatory wave (Viñoles et al. 2005, 2010b, Scaramuzzi et al. $2006,2011)$. As a consequence, we would expect shortterm supplementation to alter the balance of the oestradiol $\left(\mathrm{E}_{2}\right)$-follicle-stimulating hormone $(\mathrm{FSH})$ feedback loop, but this has been difficult to demonstrate experimentally because the waves in FSH concentration, follicle population and $E_{2}$ concentration are not synchronised among ewes during the oestrous cycle (Viñoles et al. 2010b). With respect to the effects of preand post-natal nutrition on reproductive performance as adults, the mechanisms are not known but probably include similar changes in the balance of hormones that are directly responsible for follicle growth and steroid production, perhaps also mediated by changes in the concentrations of the metabolic hormones that affect the responsiveness of follicles to gonadotrophins (Rhind et al. 2001, Scaramuzzi et al. 2011).

In this experiment, we tested the hypothesis that ewes exposed to high levels of nutrition in pre-/post-natal life would have more antral follicles, and thus a higher ovulation rate, in adult life and show a further increase in the number of healthy, potentially ovulatory follicles following a short-term supplementation with lupins, compared with ewes exposed to lower levels of nutrition in pre-/post-natal life. The presence of extra follicles in ewes that had been well-fed in early life would be associated with higher concentrations of glucose and metabolic hormones, and thus an increase in the steroidogenic capacity of healthy follicles and, therefore, low FSH concentrations. To test this hypothesis, we used the 'first-wave model' to synchronise the first follicular wave of the cycles (Viñoles et al. 2010b) of 4.9-year-old Merino ewes that had been born to mothers for which the level of nutrition had been manipulated from mating to weaning, yet were all born as singles and with a similar birth weight.

\section{Materials and methods}

The experimental procedures were approved by the Eastern Ethics Committee of the Department of Primary Industries, Hamilton, Victoria (approval number 2006-15W).

\section{Animals and pre-experimental management}

This experiment used 40 Merino ewes that were born to mothers that were in body condition score 3 (Russel et al. 1969) at mating. Thereafter, the mothers had been allocated to two groups to apply pre-/post-natal treatments to their foetuses: the 'high' pre-/post-natal nutrition group was run on high-quality pasture (3000 kg dry matter (DM)/ha) from mating through pregnancy (score 3 on day 100 of pregnancy) to weaning at $72 \pm 0.2$ days; the 'low' pre-/post-natal nutrition group was also originally in body condition score 3 at mating, but were then maintained on a low-quality pasture $(900 \mathrm{~kg}$ DM/ha) from mating through pregnancy (score 2 by day 100) to weaning (Fig. 1). The 'low' group was considered to be a control, based on the predicted liveweight changes in the Merino ewes under paddock conditions (Ferguson et al. 2011). So, the foetuses were exposed to maternal undernutrition around day 65 of pregnancy, when their ovaries are thought to be most sensitive to metabolic inputs (Rae et al. 2001).

Only single-born ewes of similar birth weight $(5.0 \pm 0.1 \mathrm{~kg}$ for high, $4.7 \pm 0.1 \mathrm{~kg}$ for low; mean \pm s.E.M.; $P>0.05$ ) were selected for the experiment. From weaning onwards, they were grazed together on a pasture-based diet on a commercial property near Hamilton in Victoria $\left(141.7^{\circ} \mathrm{E} 41^{\prime} 25 \mathrm{~s},-37.6^{\circ} \mathrm{S}\right.$ $\left.36^{\prime} 1 \mathrm{~s}\right)$ following the 'LifetimeWool' guidelines (Young et al. 2011). This involved an annual cycle with periods of liveweight loss (2-3 kg) during summer and autumn, periods of liveweight maintenance and periods of liveweight gain.

At the beginning of this study, when the ewes were $4.9 \pm 0.1$ years old, body condition score and live weight did not differ $(P>0.05)$ between the high $(2.7 \pm 0.1$ and $53 \pm 1.3 \mathrm{~kg})$ and low $(2.6 \pm 0.1$ and $51 \pm 1.3 \mathrm{~kg}$ ) groups. For the duration of the experiment, the ewes were randomly allocated to individual pens in an animal house, where they were maintained under natural lighting $(1210 \mathrm{~h}$ light and $1150 \mathrm{~h}$ darkness). They were acclimatised to these conditions for 3 weeks, during which they were individually fed a nutritionally complete, pelleted diet. The quantity offered to each ewe was calculated to meet their individual ME requirements for maintenance (CSIRO 2007), which was an average of $6.07 \mathrm{MJ} \mathrm{ME} /$ day or $674 \mathrm{~g}$ of pellets/day. The pellets were $91 \%$ DM and supplied 9.0 MJ ME and $110 \mathrm{~g}$ of crude protein $(\mathrm{CP}) / \mathrm{kg}$ (as-fed basis). The ewes were fed daily at $0000 \mathrm{~h}(0 \mathrm{~h})$ and offered water ad libitum. Feed refusals were collected and weighed daily and were $<10 \%$.

\section{Dietary treatments}

A $2 \times 2$ factorial design was used with pre-/post-natal nutrition (low or high) and lupin supplementation (with or without) as the factors, and ten animals per group (Fig. 1). During supplementation, whole lupin grain $(92 \% \mathrm{DM}, 12.6 \mathrm{MJ} \mathrm{ME}$ and $303 \mathrm{~g} \mathrm{CP} / \mathrm{kg}$ as-fed basis) was added to the pelleted maintenance diet described earlier, so supplemented animals received double their energy requirements for maintenance (Table 1). Feed refusals remained under $10 \%$.

\section{Cycle synchronisation}

All ewes received three injections of prostaglandin (PG) analogue (each $250 \mu \mathrm{g}$ cloprostenol; Juramate, Jurox Pty Ltd., Rutherford, NSW, Australia) 7 days apart in accordance with our 'first-wave' model for synchronising follicle development among ewes (Fig. 1). This allows us to apply the nutritional treatment precisely around the time of emergence of the follicle 


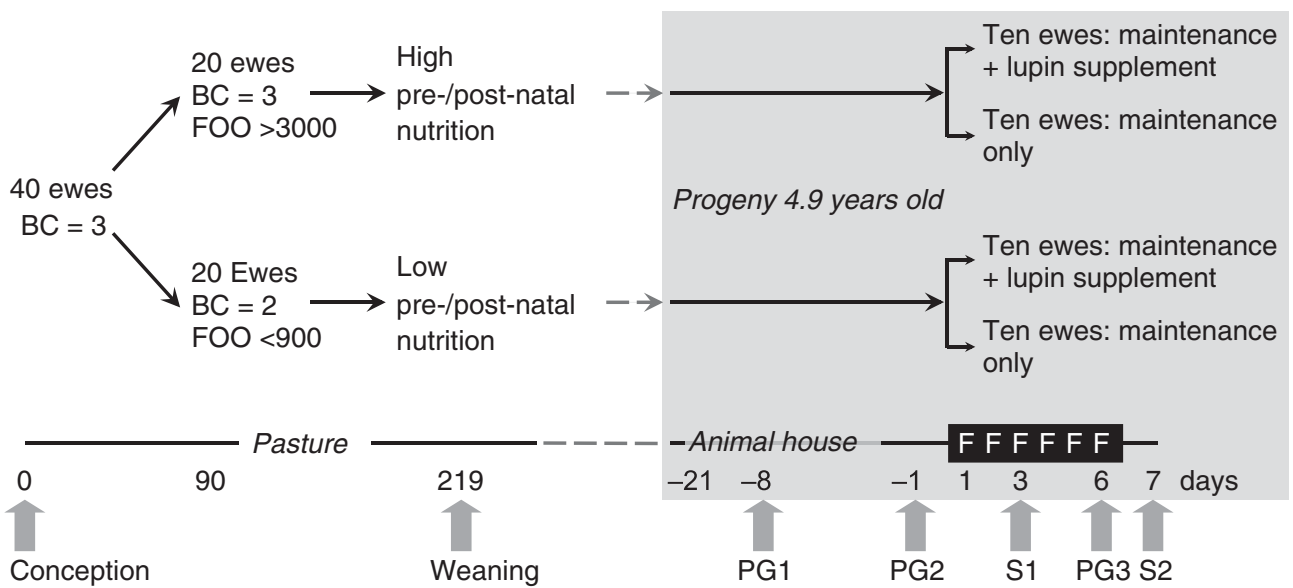

Figure $1 \mathrm{~A}$ schematic representation of the experimental design, beginning with the nutritional treatments to which the experimental ewes were exposed during pre-/post-natal life. All ewes were run together until 4.9 years of age, they were moved into an animal house (grey area) where they were fed once per day at $0000 \mathrm{~h}$. Their follicle waves were synchronised using three injections of PG analogue (PG1, PG2 and PG3). On day 1 ( 2 days after PG2 on day -1 ) half of the ewes in each group were fed daily (F) with a supplement supplying twice their requirements for maintenance for 6 days (black bar). Five ewes from each treatment were sacrificed on day 3 (S1, recruitment of follicles into the first wave of the cycle) and five ewes were sacrificed $30 \mathrm{~h}$ after PG3 (S2, selection of the pre-ovulatory follicles). BC, body condition; FOO, food on offer ( $\mathrm{kg}$ DM/ha).

wave and thus ensure that, for all animals, the peak concentrations of metabolic hormones coincide with follicle selection, when FSH concentrations are low, thus permitting co-dominance (Viñoles et al. 2010b). The 6-day period of supplementation began 2 days after the second PG injection (i.e. at the expected time of ovulation and emergence of the first follicular wave of the cycle) and continued until the third PG injection (Viñoles et al. 2010b). To facilitate the processing of tissues, the synchronisation treatment, and thus the beginning of the nutritional supplement, was staged over 3 consecutive days, with two groups of 14 and one group of 12 ewes, with each group containing all treatment combinations.

\section{Ovarian studies}

The ovaries were examined daily from the day of the second PG injection until the day of the third PG injection, using transrectal ultrasonography. We used a real-time, B-mode scanner (Aloka SSD 900 Co. Ltd., Hitachi Aloka Medical Ltd, Tokyo, Japan) with a rigid $7.5 \mathrm{MHz}$ transducer modified for external manipulation in the rectum (Viñoles et al. 2010a). The ovulation induced by the second PG injection was detected by observing the collapse of a large ( $\geq 5 \mathrm{~mm}$ ) follicle followed by the presence of luteal tissue at the same site 4 days later. For both ovaries, on each day, we noted all corpora lutea and the total number, diameter and position of all follicles of diameter $\geq 2 \mathrm{~mm}$. The accuracy and precision of this procedure has been confirmed by analyses of scanned ovaries post-mortem (Viñoles et al. 2004). A follicular wave was defined as one or more follicles growing to at least $5 \mathrm{~mm}$ in diameter. Groups of follicles emerging within $48 \mathrm{~h}$ were regarded as a single follicular wave. A subordinate follicle was defined as a follicle that reached $3 \mathrm{~mm}$ and could be followed by ultrasonography for at least 3 days. The characteristics of follicular waves were described in relation to measures of the largest follicle: day of emergence, maximum diameter and day of maximum diameter
(Viñoles et al. 2001). The day of wave emergence was deemed as the day the largest follicle of the wave (identified retrospectively) reached $2-3 \mathrm{~mm}$ in diameter. Lifespan was defined as the number of days between emergence and ovulation.

\section{Dissection of the ovarian follicles}

Ovaries from five animals in each group were recovered 3 days after the start of supplementation (recruitment of follicles into the first wave of the cycle) and from the other five animals $30 \mathrm{~h}$ after the third PG injection (selection of the pre-ovulatory follicles). The numbers of corpora lutea were counted to confirm the ultrasonographic observations. All individual follicles of diameter $\geq 3 \mathrm{~mm}$ were dissected free of extraneous tissue in PBS under a stereomicroscope with their diameters recorded to the nearest $0.5 \mathrm{~mm}$. A small slit was made in the follicle wall to allow the antral fluid to escape into a Petri dish, from where it was aspirated through a finely drawn-out Pasteur pipette, taking care not to remove clumps or sheets of granulosa cells. A known volume of the follicular fluid was added to $100 \mu \mathrm{l} \mathrm{PBS}$ and frozen at $-20^{\circ} \mathrm{C}$ for subsequent measurement of $E_{2}$ concentrations, the most reliable indicator of the health status of antral follicles over a wide range of sizes (McNatty et al. 1985). The granulosa cells were recovered and counted by using haemocytometer. To help classify follicles as nonatretic or atretic, the presence or absence of thecal blood

Table 1 Average amount of metabolisable energy and crude protein offered to control and supplemented ewes that been previously exposed to low or high pre-/post-natal nutrition.

\begin{tabular}{lccc}
\hline $\begin{array}{l}\text { Pre-/post-natal } \\
\text { nutrition }\end{array}$ & $\begin{array}{c}\text { Acute supple- } \\
\text { mentation }\end{array}$ & $\begin{array}{c}\text { Metabolisable } \\
\text { energy (M)/day) }\end{array}$ & $\begin{array}{c}\text { Crude } \\
\text { protein (g/day) }\end{array}$ \\
\hline Low & + & 11.9 & 215.4 \\
Low & - & 6.0 & 73.4 \\
High & + & 12.2 & 220.7 \\
High & - & 6.2 & 76.4 \\
\hline
\end{tabular}


capillaries (at 10× magnification) and of debris in follicular fluid were noted. In addition, after removal of the granulosa cells, the colour of the theca interna (i.e. red, pink or white) was recorded. For the purpose of this study, a healthy follicle was defined as one with i) visible thecal blood capillaries, ii) follicular fluid devoid of debris, iii) a pink- to red-coloured theca interna, iv) a normal-looking and intact oocyte-cumulus cell complex and v) more than $25 \%$ of the maximum number of granulosa cells for a given follicle size (McNatty et al. 1985). Conversely, an atretic follicle was one to which any of these criteria did not apply.

\section{Granulosa cell aromatase assay}

Granulosa cells from individual healthy follicles were collected into PBS and $1 \%(\mathrm{w} / \mathrm{v})$ BSA. They were washed and resuspended in $\mathrm{PBS}$ and $1 \% \mathrm{BSA}$ so that the final cell concentration was $6 \times 10^{4}$ granulosa cells $/ \mathrm{ml} ; 0.15 \mathrm{ml}$ aliquants of these cell suspensions were placed in $10 \times 75 \mathrm{~mm}$ plastic tubes containing $0.15 \mathrm{ml}$ of PBS and 1\% BSA solution with or without $2000 \mathrm{ng}$ testosterone $/ \mathrm{ml}$. The cell suspensions were gassed with $5 \% \mathrm{CO}_{2}$ in air, sealed and then incubated for $3 \mathrm{~h}$ in a shaking water bath at $37^{\circ} \mathrm{C}$. At the end of the incubation, the tubes containing medium plus cells were frozen at $-20^{\circ} \mathrm{C}$. Subsequently, the contents of the tubes were thawed, centrifuged and the supernatants were assayed for $E_{2}$.

\section{Blood sampling, glucose and hormone assays}

From the day before the initiation of the nutritional treatment until the day of the third PG injection, jugular blood $(5 \mathrm{ml})$ was sampled daily, $1 \mathrm{~h}$ before feeding $(0 \mathrm{~h})$, into tubes that contained heparin and potassium oxalate. On days $-1,3$ and 6 from the initiation of the nutritional treatment (day 0), blood was sampled at $-1,3.5$ and $7 \mathrm{~h}$ relative to feeding. The samples were kept on ice and plasma was separated by centrifugation within $10 \mathrm{~min}$ of sampling and stored at $-20^{\circ} \mathrm{C}$ until assayed.

Plasma progesterone was assayed in duplicate using a standard RIA kit (Diagnostic Systems Laboratories, Inc., Webster, TX, USA) as described elsewhere (Gray et al. 2000). Only samples collected at $-1 \mathrm{~h}$ relative to feeding were assayed. The limit of detection was $0.3 \mathrm{ng} / \mathrm{ml}$. The intra-assay coefficients of variation (CV) were $2.8 \%$ for low $(1.2 \mathrm{ng} / \mathrm{ml})$ and $4.2 \%$ for high $(9.9 \mathrm{ng} / \mathrm{ml})$ progesterone values in plasma, and inter-assay CV were 2.3 and $17.4 \%$ respectively.

$\mathrm{E}_{2}$ was assayed in a single RIA using an Adaltis MAIA Oestradiol Kit from Diagnostic Technology (Belrose, NSW, Australia). Plasma samples collected at $-1,3.5$ and $7 \mathrm{~h}$ relative to feeding were pooled to obtain a daily profile. $E_{2}$ was extracted from $400 \mu \mathrm{l}$ plasma and $200 \mu \mathrm{l}$ quality controls and standards using $2 \mathrm{ml}$ diethyl ether with an extraction efficiency of $88 \pm 2 \%$. The limit of detection was $3 \mathrm{pmol} / \mathrm{l}$. The intra-assay CV was $4.9 \%$ for concentrations of $11 \mathrm{pmol} / \mathrm{l}$ and $16.4 \%$ for concentrations of $35 \mathrm{pmol} / \mathrm{l}$. The inter-assay CV was 25 and $18.5 \%$ for low and high $\mathrm{E}_{2}$ concentrations respectively. Concentrations of $E_{2}$ in follicular fluid and the medium from granulosa cell cultures were measured using the same kit described earlier, except that samples were not extracted.
The limit of detection of the assay was $3.7 \mathrm{pmol} / \mathrm{l}$. The intraassay $\mathrm{CV}$ was $10 \%$ for concentrations of $21 \mathrm{pmol} / \mathrm{l}$ and $11 \%$ for concentrations of $58 \mathrm{pmol} / \mathrm{l}$. The inter-assay $\mathrm{CV}$ was 8 and $2 \%$ for the low and high $\mathrm{E}_{2}$ concentrations respectively.

As samples of follicular fluid were further diluted 1/100 in preparation for the assay, values were multiplied by 1000 to express the concentrations $(\mathrm{nmol} / \mathrm{l})$. The $\mathrm{E}_{2}$ production by granulosa cells was calculated based on the following formula: $\left(E_{2}\right.$ concentrations (pmol/tube)/assay volume $(\mu \mathrm{l}) \times 600 /$ $1000) /\left(\right.$ cell number $\left.\left(\times 10^{6}\right) \times 1000000\right)$, and expressed (nmol $E_{2}$ /million granulosa cells).

Plasma concentrations of FSH were measured in a single RIA using reagents kindly supplied by Dr A F Parlow of the National Institute of Diabetes, Digestive and Kidney Disease (Baltimore, MD, USA), as described previously (Martin et al. 1994). The samples were assayed as duplicate $100 \mu \mathrm{l}$ aliquants and the limit of detection was $0.5 \mathrm{ng} / \mathrm{ml}$. Pooled plasma samples (six replicates) containing $1.5,2.4$ and $3.2 \mathrm{ng} / \mathrm{ml}$ were used to determine intra-assay CV: 2.2, 3.0 and $3.2 \%$. The inter-assay CV were $1.6,1.9$ and $2.2 \%$ for the low, medium and high quality controls.

Glucose concentrations were determined spectrophotometrically in samples collected with fluoride-oxalate as the anticoagulant. Concentrations were measured in a Cobas Mira Autoanalyser (Hoffman-La Roche Diagnostica) with an Infinity Glucose Hexokinase Kit (cat no. TR15421, Thermo Electron Co., Melbourne, VIC, Australia). The intra and inter-assay CV for the quality control $(5.3 \mathrm{mmol} / \mathrm{l})$ were 3.2 and $4.9 \%$.

Plasma insulin was assayed in duplicate in a single doubleantibody RIA (Tindal et al. 1978) that had been validated for sheep plasma in our laboratory (Miller et al. 1995). The limit of detection was $1.2 \mathrm{mU} / \mathrm{ml}$. The assay included six replicates of control samples containing 2.7, 4.1 and $9.3 \mathrm{mU} / \mathrm{ml}$, for which the intra-assay CV were 9.1, 5.5 and $7.6 \%$.

Leptin was assayed in all samples in a single double-antibody RIA using an antibody raised against recombinant bovine leptin in an emu, as described in detail by Blache et al. (2000). The samples were assayed as duplicate $100 \mu \mathrm{l}$ aliquants and the limit of detection was $0.3 \mathrm{ng} / \mathrm{ml}$. Six replicates of three control samples containing $0.1,0.4$ and $1.04 \mathrm{ng} / \mathrm{ml}$ were included in the assay to estimate the intra-assay $\mathrm{CV}$, which were $20.4,6.8$ and $7.2 \%$.

Plasma concentrations of insulin-like growth factor 1 (IGF1) were measured in a single double-antibody RIA (Gluckman et al. 1983) after interference by binding proteins had been minimised using an acid-ethanol cryoprecipitation, as validated for ruminant samples (Breier et al. 1991). The samples were assayed as duplicate $100 \mu \mathrm{l}$ aliquants and the limit of detection was $0.4 \mathrm{ng} / \mathrm{ml}$. Six replicates of two control samples, containing 0.44 and $2.42 \mathrm{ng} / \mathrm{ml} \mathrm{IGF1,} \mathrm{were} \mathrm{included}$ in the assay and were used to estimate the intra-assay CV (11.1 and $10.3 \%$ ).

\section{Statistical analyses}

Categorical data, such as the proportions of animals that developed a second follicular wave during the experimental period, were analysed by the GENMOD procedure in the Statistical Analysis System (SAS, 9.1.3, SAS Institute, Inc., Cary, 
NC, USA). The effects of pre-/post-natal nutrition, supplementation, and the interaction of these two factors, on ovulation rate were compared using a generalised lineal model with a binomial distribution $(0$, single ovulation and 1 , double ovulation) after log transformation of the data. A logistic regression was used to test whether the presence or absence of follicles was affected by pre-/post-natal nutrition, supplementation and day (3 or 7) from the start of feeding. A second set of data was created using the animals that had follicles to analyse the impact of pre-/post-natal nutrition, supplementation and day ( 3 or 7 ) on the status (healthy or atretic) and size class (3, 4 and $5 \mathrm{~mm}$ ) of follicles. Data that involved repeated measurements (e.g. plasma hormone concentrations and follicular development) were analysed by the mixed-model procedure of SAS, including the fixed effects of time, day of sacrifice, pre-/post-natal nutrition, and supplement, and their interactions. The normality of the data and the presence of outliers were checked using the univariate procedure available in SAS. The covariance structure was modelled using the random effect of ewe-within-group plus autoregressive order 1 , to account for the correlation between sequential measurements within the same animal (Littell et al. 2000). Mean values were compared using least squares means and considered significant if $P<0.05$ and tendencies for $0.05<P<0.1$. Data are presented as least square means \pm pooled standard errors.

\section{Results}

\section{Follicular dynamics}

The growth profile and maximum diameter of the follicles that were induced to ovulate by the second PG injection (before the beginning of the supplementation period) did not differ between groups $(P>0.05)$. Figure 2 shows that the ovulatory follicle grew in parallel with a decrease in the concentrations of progesterone and an increase in the concentrations of $E_{2}$. The characteristics of the dominant follicle of the first wave (day of emergence, lifespan, maximum diameter and growth rate) also did not differ between groups $(P>0.05)$. FSH concentrations increased in all groups before the emergence of the first follicular wave, with associated changes in the number of follicles $\geq 3 \mathrm{~mm}$ in diameter (Fig. 2). Progesterone concentrations increased from day 3 after the start of the nutritional treatment and

\section{Low pre-/post-natal nutrition}

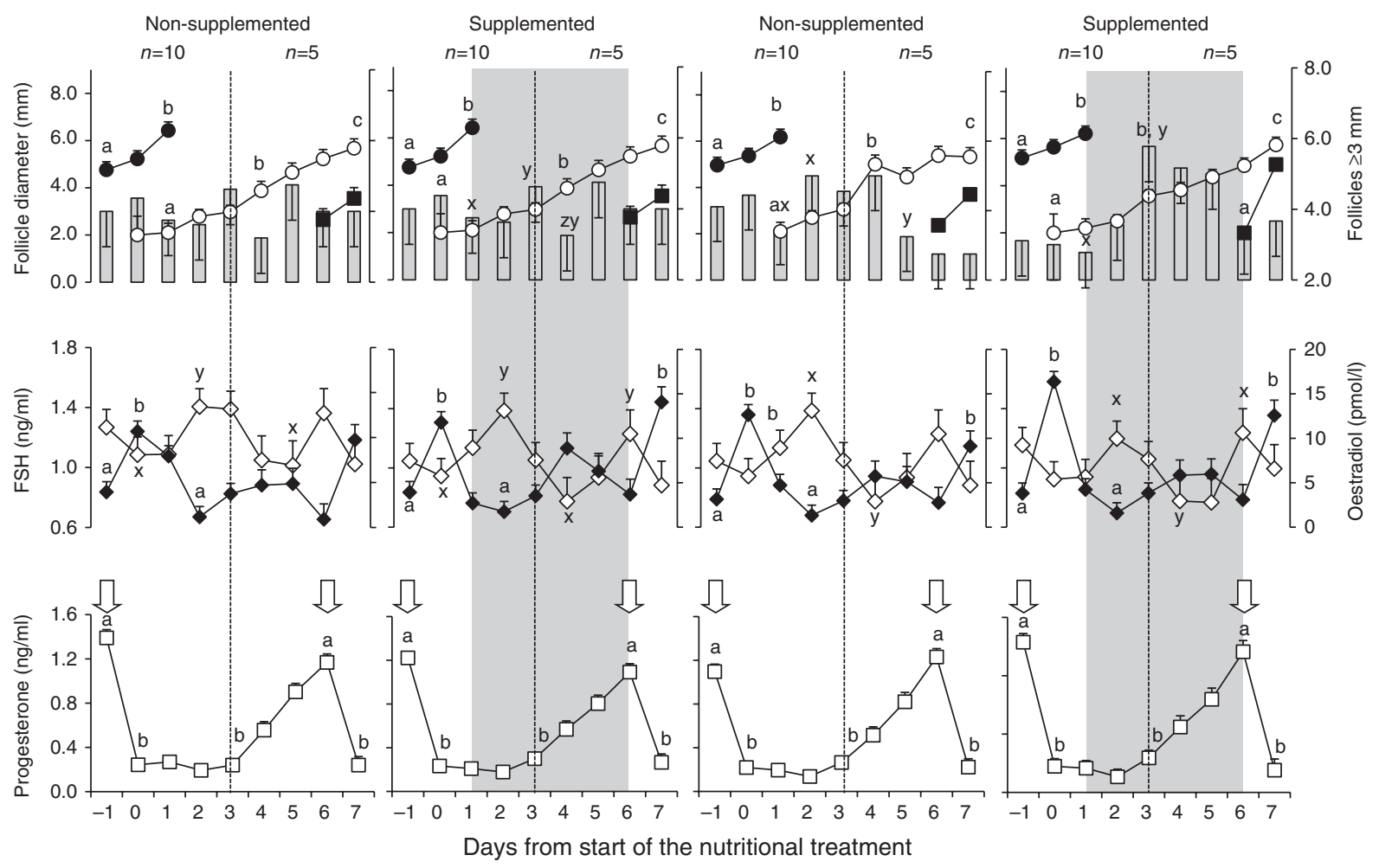

Figure 2 Growth profile of the follicle induced to ovulate after the second PG injection (black circle), the dominant follicle of the first (white circle) and the second follicular waves (black square) of the cycle, in association with the numbers of 3-mm follicles (grey bars, upper panel) and the plasma concentrations of FSH (white diamond), oestradiol (black diamond; middle panel) and progesterone (lower panel; white square) in ewes exposed to low and high pre-/post-natal nutrition, that were not supplemented or fed a nutritional supplement for 6 days (from day 1 shaded area). Arrows indicate the time of the second and third PG injections. The broken lines on day 3 indicate sacrifice of five ewes, reducing the number of ewes by half in each treatment group. All values are least squares means ( \pm s.E.M.). a vs b vs $c$, indicates significant changes in the profile of follicle growth and hormonal concentrations within the same group of ewes. $x$ vs y vs $z$, indicates significant changes in the number of $>3 \mathrm{~mm}$ follicles between days within the same group of ewes. 
Table 2 Numbers of atretic and healthy follicles in 3, 4 and $5 \mathrm{~mm}$ size classes found in the groups of five ewes sacrificed on days 3 or 7 of the period of supplementation. Data are combined across all treatments (exposure to low and high pre-/post-natal nutrition; maintenance-fed or supplemented with lupin grain).

\begin{tabular}{lccccc}
\hline Status & \multicolumn{3}{c}{ Atretic } & & \multicolumn{2}{c}{ Healthy } \\
\cline { 1 - 4 } \cline { 5 - 6 } $\begin{array}{l}\text { Days of } \\
\text { sacrifice }\end{array}$ & 3 & 7 & & 3 & 7 \\
\hline $3 \mathrm{~mm}$ & 6 & 2 & & $15^{\mathrm{a}}$ & $7^{\mathrm{b}}$ \\
$4 \mathrm{~mm}$ & 8 & 4 & & $11^{\mathrm{a}}$ & $3^{\mathrm{b}}$ \\
$5 \mathrm{~mm}$ & 4 & 5 & & $6^{\mathrm{a}}$ & $20^{\mathrm{b}}$ \\
Total & 18 & 11 & & $32^{\mathrm{a}}$ & $30^{\mathrm{a}}$ \\
\hline
\end{tabular}

a vs b compare numbers of healthy follicles at different days of sacrifice.

peaked on day 6 in all groups (Fig. 2). The proportion of ewes developing a second follicular wave (high early nutrition, non-supplemented $=2 / 5$; high early nutrition, supplemented $=1 / 5$; low early nutrition, non-supplemented $=3 / 5$ and low early nutrition, supplemented $=2 / 5$ ) and the growth profile of the largest follicle of the second wave did not differ between groups $(P>0.05)$. In the supplemented groups, FSH concentrations increased significantly with the emergence of the second follicular wave. The final growth of the pre-ovulatory follicles induced by the third PG injection occurred in parallel with a decrease in progesterone and an increase in $E_{2}$ concentrations (Fig. 2).

Ovulation rate, as determined by the number of corpora lutea detected by ultrasonography after the second PG injection and confirmed by direct observation post-mortem, was higher with exposure to high $(1.5 \pm 0.1)$ than to low pre-/post-natal nutrition $(1.2 \pm 0.3 ; P<0.05)$.

Pre-/post-natal nutrition, supplementation and day had no effect on the presence or absence of follicles $(P>0.05)$, or on the status (atretic or healthy) of follicles. However, the number of healthy follicles in the different size classes was affected by day after commencement of feeding (Table 2) - there were more 3 and $4 \mathrm{~mm}$ healthy follicles on day 3 , but more $5 \mathrm{~mm}$ healthy follicles on day $7(P<0.001)$.

\section{Granulosa cells and $E_{2}$ concentrations}

The size of the largest healthy follicle $(6.1 \pm 0.2 \mathrm{~mm})$ and its number of granulosa cells $(3.7 \pm 0.2$ million) were greater in supplemented than in non-supplemented ewes $(5.4 \pm 0.2 \mathrm{~mm}$ and $3.0 \pm 0.2$ million; $P<0.05)$ irrespective of day of supplementation or of pre-/post-natal nutrition treatment. The antral fluid concentrations of $E_{2}$ in healthy follicles were affected by the supplement $(P<0.05)$ and by the interaction between supplement, pre-/post-natal nutrition and day $(P<0.01)$. The supplement decreased the $E_{2}$ concentrations in follicular fluid in ewes from both the low and high pre-/post-natal nutrition groups on day 7 (Table 3 ).
The capacity of the granulosa cells from healthy follicles to produce $E_{2}$ from testosterone was not affected by pre-/post-natal nutrition, supplementation, or the interaction between these factors. The concentration of $\mathrm{E}_{2}$ was higher on day $7\left(85.2 \pm 5.5 \mathrm{nmol} \mathrm{E}_{2} /\right.$ million granulosa cells) than on day $3(50.7 \pm 5.9 \mathrm{nmol}$ $\mathrm{E}_{2} /$ million granulosa cells) $(P<0.001)$.

\section{Circulating concentrations of hormones and glucose}

Ewes that had been exposed to high pre-/post-natal nutrition tended $(P=0.055)$ to have lower $\mathrm{FSH}$ concentrations during the experimental period $(1.0 \pm 0.03 \mathrm{ng} / \mathrm{ml})$ than ewes that had been exposed to low pre-/post-natal nutrition $(1.1 \pm 0.03 \mathrm{ng} / \mathrm{ml})$. Supplemented ewes had lower FSH concentrations $(1.0 \pm 0.03 \mathrm{ng} / \mathrm{ml})$ than non-supplemented ewes $(1.1 \pm 0.03 \mathrm{ng} / \mathrm{ml} ; P<0.01)$. Plasma $\mathrm{E}_{2}$ concentrations were not affected by pre-/post-natal nutrition but, overall, values were higher in supplemented $(4.6 \pm 0.3 \mathrm{pmol} / \mathrm{l})$ than in non-supplemented ewes $(3.9 \pm 0.3 \mathrm{pmol} / \mathrm{l}$; $P<0.05)$. Maximum $\mathrm{E}_{2}$ concentrations tended to be higher in supplemented $(11.2 \pm 0.8 \mathrm{pmol} / \mathrm{l})$ than in non-supplemented ewes $(9.2 \pm 0.8 \mathrm{pmol} / / ; P=0.09)$.

Concentrations of glucose were affected by supplementation, day and the interaction between these two factors (Figs 3 and 4), but not by pre-/post-natal or time after feeding $(P>0.05)$. In non-supplemented groups, concentrations decreased from days 2 to 7 (Fig. 4) while in supplemented groups, concentrations reached maximum values on day 4 and decreased thereafter. Overall, supplemented ewes had slightly higher glucose concentrations $(3.4 \pm 0.03 \mathrm{mmol} / \mathrm{l})$ than non-supplemented ewes $(3.3 \pm 0.03 \mathrm{mmol} / \mathrm{l} ; P<0.01)$, but concentrations were similar in ewes from the high $(3.3 \pm 0.03 \mathrm{mmol} / \mathrm{l})$ and low $(3.3 \pm 0.03 \mathrm{mmol} / \mathrm{l})$ pre-/post-natal nutrition treatments (Fig. 4). However, the effect of supplementation on pre-feeding glucose concentration was greater in ewes that had received low nutrition than those that had received high nutrition during pre-/postnatal life (days 3 and 6 of feeding; Fig. 4).

Concentrations of insulin were affected by pre-/postnatal nutrition, supplementation, day, hour and the interaction between these factors. Ewes that had received high pre-/post-natal nutrition tended $(P=0.07)$ to have higher insulin concentrations $(7.7 \pm 0.28 \mu \mathrm{U} / \mathrm{ml})$

Table 3 Oestradiol (nmol/l) concentrations in follicular fluid in ewes that had been exposed to low and high pre-/post-natal nutrition and then had received or not $( \pm)$ a 6-day supplement of lupin grain.

\begin{tabular}{lccccr}
\hline & \multicolumn{2}{c}{-Supplement } & & \multicolumn{2}{c}{ +Supplement } \\
\cline { 2 - 3 } \cline { 5 - 6 } Days & 3 & 7 & & 3 & 7 \\
\hline Low & $61.7 \pm 20.9^{\mathrm{a}}$ & $259.2 \pm 54.0^{\mathrm{b}}$ & & $88.8 \pm 31.2^{\mathrm{a}}$ & $70.8 \pm 46.6^{\mathrm{a}}$ \\
High & $47.0 \pm 20.9^{\mathrm{a}}$ & $242.3 \pm 47.0^{\mathrm{b}}$ & & $77.5 \pm 35.2^{\mathrm{a}}$ & $121.9 \pm 35.2^{\mathrm{a}}$ \\
\hline
\end{tabular}

Within rows and between columns a vs $b, P<0.01$. 
compared with those that had received low pre-/postnatal nutrition $(7.0 \pm 0.28 \mu \mathrm{U} / \mathrm{ml})$. On the day before the initiation of the nutritional treatment, peak insulin values were observed at $7 \mathrm{~h}$ after feeding in all groups, and the peaks were generally advanced to $3.5 \mathrm{~h}$ on days 3 and $6(P<0.001 ;$ Fig. 3$)$. In non-supplemented groups, concentrations remained unchanged during the treatment period (Figs 3 and 4). In supplemented groups, on the other hand, insulin dynamics differed between ewes that had been exposed to high or low pre-/post-natal nutrition. Concentrations increased from day 1 to reach maximum values on day 3 in the high group, whereas maximum values were delayed until day 5 in the low group, with a subsequent decrease only observed in the low group.

Concentrations of leptin were affected by supplementation, day and the interaction between the two factors, but they were not affected by pre-/post-natal nutrition. Within each day, values remained relatively stable with time after feeding (Fig. 3). They also did not change over days -1 to 7 of the supplementation period in the non-supplemented groups (Fig. 4), but in the supplemented groups they increased on day 1 and remained elevated until day 7 . Overall, concentrations were higher in supplemented $(1.2 \pm 0.03 \mathrm{ng} / \mathrm{ml})$ than in non-supplemented ewes $(0.9 \pm 0.03 \mathrm{ng} / \mathrm{ml})$, the differences being significant from days 2 to 7 only in high pre-/post-natal nutrition ewes $(P<0.01$; Fig. 4$)$.

Plasma IGF1 concentrations were also affected by supplementation, day and the interaction between the two factors, but not by pre-/post-natal nutrition or time after feeding (Fig. 3). Supplemented ewes $(33.0 \pm 1.28 \mathrm{ng} / \mathrm{ml})$ had higher IGF1 concentrations than non-supplemented ewes $(22.0 \pm 1.28 \mathrm{ng} / \mathrm{ml} ; P<0.001$; Fig. 4). Overall, concentrations decreased from days -1 to 6 in non-supplemented ewes while, in supplemented ewes, they remained similar or increased (Fig. 4). A steep decay was observed from days 2 to 4 in supplemented ewes that had received high pre-/post-natal nutrition, but the values recovered thereafter (Fig. 4).

\section{Discussion}

The effect of nutrition in early life on ovulation rate in adult life agrees with observations by Rae et al. (2002), who studied 20-month old ewes. However, the level of nutrition in early life did not affect the size of the population of healthy antral follicles or the numbers of granulosa cells in the largest follicles, so as would be expected it did not affect $E_{2}$ production. On the other hand, FSH concentrations were lower in ewes that received high pre-/post-natal nutrition than in those that received low pre-/post-natal nutrition. Although we did not detect an increase in the number of follicles recruited into the ovulatory wave, ovulation rate was higher in ewes fed well in early life than in those fed poorly in early life. Acute supplementation did not affect the size of the population of healthy follicles, but it did increase the size of the largest follicle and its number of granulosa cells and thus the concentrations of $E_{2}$, probably explaining the lower concentrations of $\mathrm{FSH}$ in supplemented than non-supplemented ewes. Thus, as with acute supplementation (Viñoles et al. 2010a, 2010b), the increase in ovulation rate caused by good early nutrition is associated with a reduction in FSH concentrations.

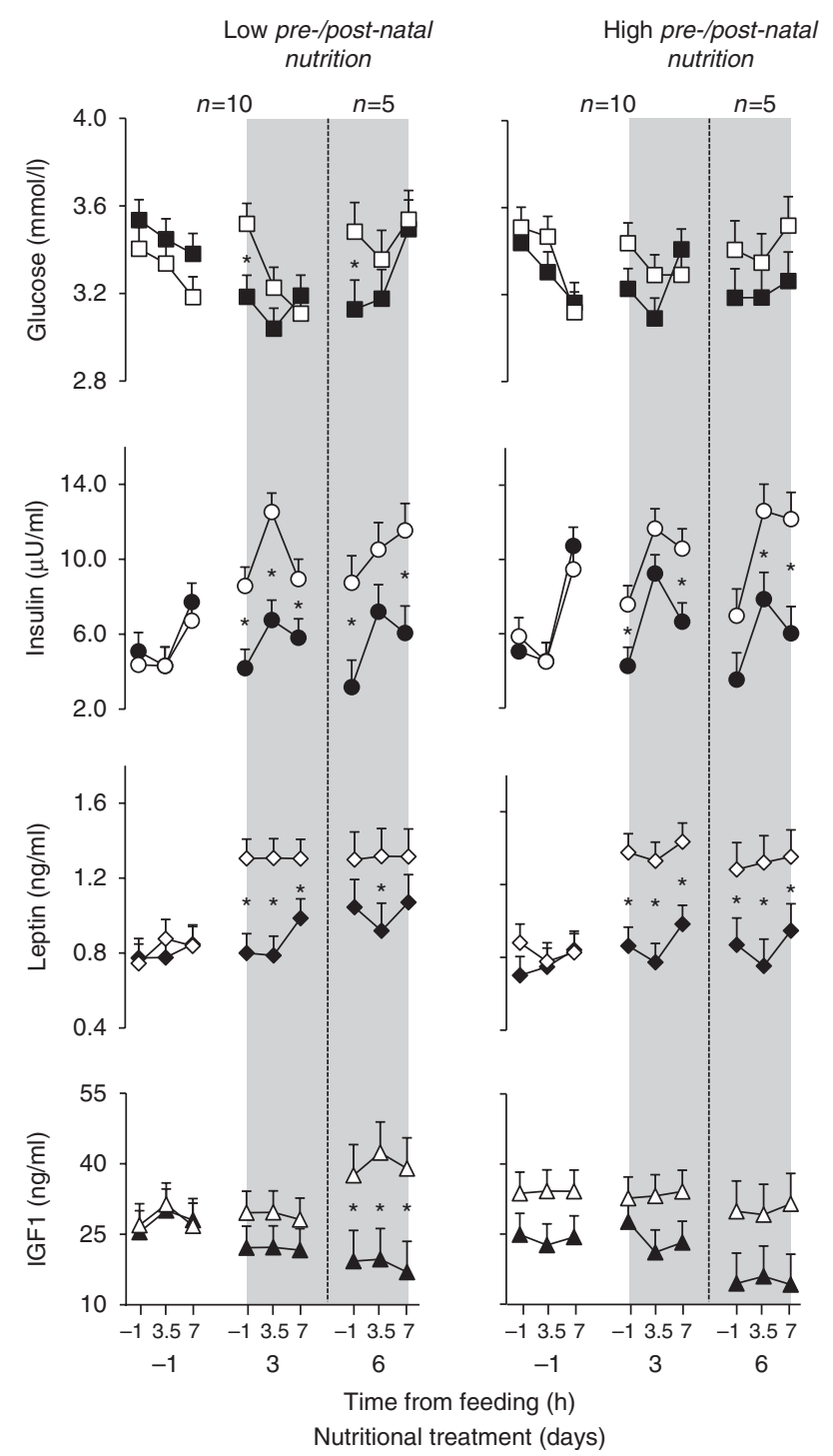

Figure 3 Changes in the plasma concentrations of glucose (square), insulin (circle), leptin (diamond) and IGF1 (triangle) in ewes exposed to low and high pre-/post-natal nutrition, non-supplemented (black symbols) or supplemented with lupins (white symbols) for 6 days (shaded area). Samples were taken at $-1,3.5$ and $7 \mathrm{~h}$ (relative to the time of feeding at $0 \mathrm{~h}$ ) on day -1 ( 2 days before the start of supplementation) and the third and the final day of supplementation. The broken line indicates the day of sacrifice of five ewes, reducing the number of ewes by half in each treatment group. *Significant differences between supplemented and non-supplemented ewes. All values are least squares means ( \pm s.E.M.). Note that on day 6 , the number of ewes was reduced to five in each treatment. 


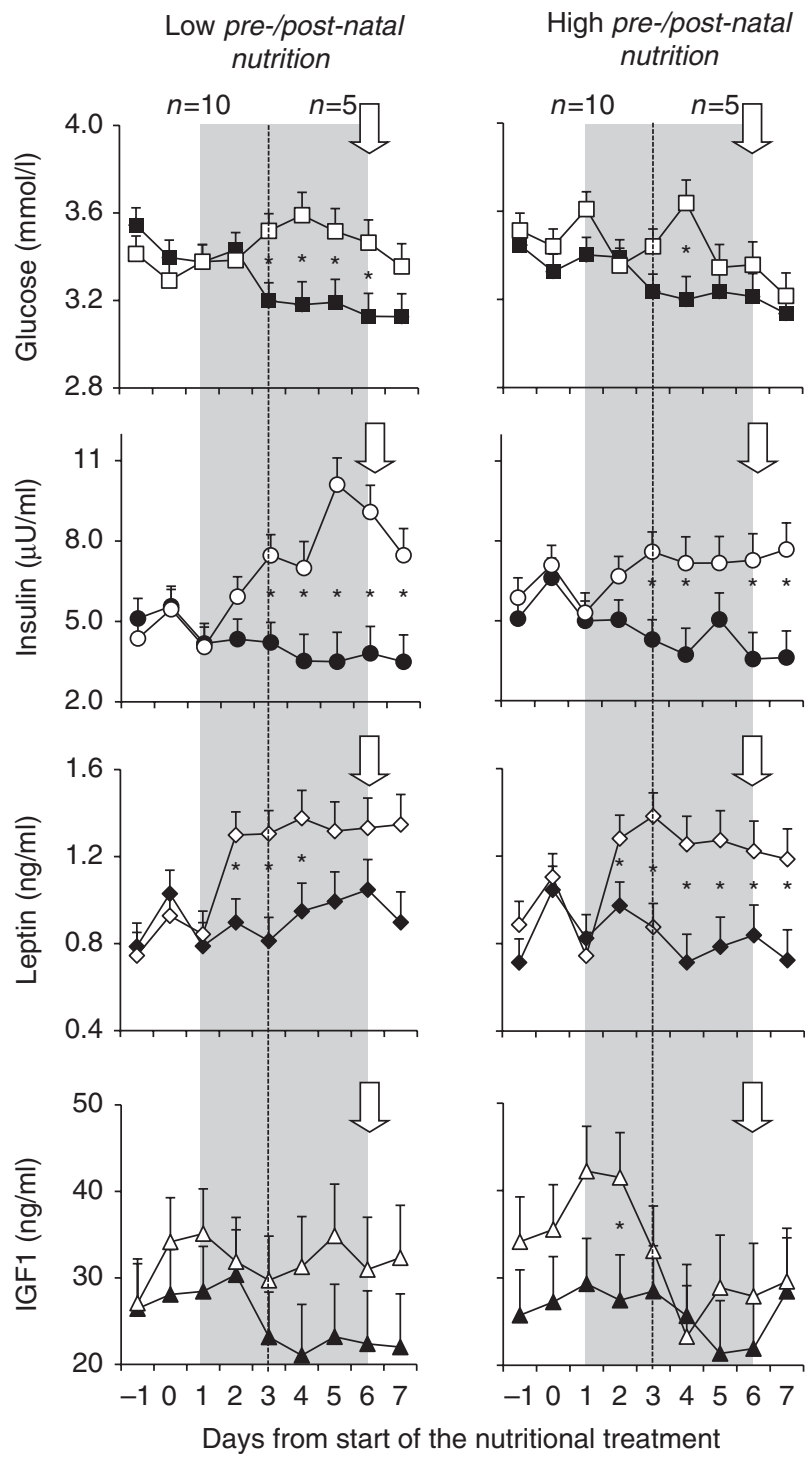

Figure 4 Changes in the plasma concentrations of glucose (square), insulin (circle), leptin (diamond) and IGF1 (triangle) in ewes exposed to low and high pre-/post-natal nutrition, and either non-supplemented (black symbols) or supplemented with lupin grain (white symbols) for 6 days (shaded area). Samples were taken daily, from 2 days before supplementation started until the day after the end of the

supplementation. Arrows indicate the time of the second and third PG injections. The broken line indicates the day of sacrifice of five ewes, reducing the number of ewes by half in each treatment group. * Significant differences between supplemented and non-supplemented ewes. All values are least squares means ( \pm s.E.M.).

This suggests that, in both situations, increases in ovulation rate must be accompanied by increases in the responsiveness of follicles to $\mathrm{FSH}$, perhaps due to the actions of metabolic factors within the ovary, including those involved in glucose homoeostasis (Scaramuzzi et al. 2011). The level of nutrition in early life had no major effect on the circulating concentrations of glucose or metabolic hormones, but did elicit a small change in the concentrations of insulin. Short-term supplementation markedly increased the circulating concentrations of glucose and metabolic hormones. We therefore suggest that the level of nutrition in early life leads to long-term effects on the dynamics of the metabolic and reproductive hormones that affect the final stages of follicular selection, and thus ovulation rate. However, early nutrition does not seem to affect the metabolic or ovarian responses to acute supplementation.

Nutrition in early life did not influence the effect of short-term supplementation on the number of healthy pre-ovulatory follicles, but the pooled data from the two early-nutrition groups lead to new insights into the mechanisms involved in the ovarian response to shortterm supplementation. Supplemented ewes had a larger healthy follicle with $20 \%$ more granulosa cells and produced $20 \%$ more circulating $\mathrm{E}_{2}$. Granulosa cells are the richest source of aromatase activity and thus $\mathrm{E}_{2}$ (McNatty et al. 1984), but the increased steroidogenic capacity of the follicles in lupin-fed ewes was associated with the increases in granulosa cell numbers but not aromatase activity. The increased production of $E_{2}$ was associated with a decrease in $\mathrm{FSH}$ concentrations in supplemented ewes. These observations are coherent with our previous studies of 6-day supplementation with the 'first-wave model' (Viñoles et al. 2010b). Using an alternative to the 'first-wave' experimental model, we have also shown that supplementation with corn plus soya bean meal for 6 days during the mid-luteal phase leads to the development of larger preovulatory follicles (Viñoles et al. 2005) and, under field conditions, induces a 15\% increase in ovulation rate (Viñoles et al. 2009). Therefore, across a range of experimental protocols, the common theme is that acute supplementation induces a larger and more oestrogenic pre-ovulatory follicle that reduces $\mathrm{FSH}$ concentrations yet allows the selection of extra follicles, thus leading to an increase in ovulation rate.

As mentioned earlier, decreased FSH concentrations are compatible with increased selection of pre-ovulatory follicles if the response to FSH is amplified by, for example, increased concentrations of glucose and metabolic hormones (Scaramuzzi et al. 2011). In this experiment, the 6-day lupin supplement increased the circulating concentrations of glucose, insulin, leptin and IGF1, as seen previously (Viñoles et al. 2005, 2010b, Scaramuzzi et al. 2006, 2011). In this study, the changes associated with feed intake were evident for insulin, but not for glucose or leptin concentrations, in contrast to previous observations (Marie et al. 2001, Viñoles et al. 2005). The peak concentrations of glucose and the metabolic hormones occurred between days 2 and 5 after the start of feeding, a degree of variation that contrasts with the consistent increase on day 3 observed previously (Teleni et al. 1989, Viñoles et al. 2005), and that appears to be explained by the level of pre-/post-natal nutrition. These metabolic factors can change the internal endocrine milieu of the follicle - for example, leptin 
decreases the stimulatory action of IGF1 on steroidogenesis - decreasing the concentrations of $\mathrm{E}_{2}$ in the antral fluid and increasing the likelihood that growing follicles will survive in the presence of low FSH concentrations (Spicer et al. 2002, Scaramuzzi et al. 2006).

This study is based on our 'first-wave' experimental model in which waves of $\mathrm{FSH}$, follicular growth and $\mathrm{E}_{2}$ are tightly synchronised among ewes so as to increase experimental power (Viñoles et al. 2010b). The first-wave model is effective in that regard, but the low progesterone concentrations produced by a newly formed and short-life corpus luteum may create an abnormal endocrine milieu (e.g. increased LH pulse frequency) with negative consequences for the development of the pre-ovulatory follicle, the competence of the oocyte and fertility (Sirois \& Fortune 1990, Viñoles et al. 2001, 2012, Fierro et al. 2011). The development of an alternative approach for synchronising the emergence of waves of follicles during the luteal phase might be useful; therefore, for testing whether changes in the $E_{2}-F S H$ feedback loop is indeed an effect of nutrition or a consequence of the 'first-wave' model.

\section{Conclusions}

Exposure to high levels of nutrition in early life increases ovulation in adult ewes, 5 years later, in association with changes in insulin-glucose homoeostasis and $\mathrm{E}_{2}-\mathrm{FSH}$ balance. These responses are similar to those following acute nutritional supplementation. It appears that, in both situations, metabolic factors amplify the effect of FSH on follicle development, thus overcoming any effects of a decrease in FSH concentrations caused by the development of a larger steroidogenic follicle, allowing co-dominance and an increase in ovulation rate. The responses to early nutrition and acute supplementation do not appear to interact.

\section{Declaration of interest}

The authors declare that there is no conflict of interest that could be perceived as prejudicing the impartiality of the research reported.

\section{Funding}

This work was funded by Meat and Livestock Australia (LambMax Australia MS.027), the University of Western Australia (Startup Funds for Research Initiatives, Faculty of Natural and Agricultural Sciences), Australian Wool Innovation Ltd. (Lifetime Wool) and the Victorian Department of Primary Industries.

\section{Acknowledgements}

The authors would like to thank David and Fiona Robertson of Austral Park for providing the research site and experimental sheep. We gratefully acknowledge the efforts of Dr Kirsty
Thompson, Sandra Greenaway and staff from the Department of Primary Industries in Hamilton who coordinated the on-farm trial and prepared and assisted in the animal house study. We thank Margaret Blackberry for her invaluable help in the analysis of the hormonal samples and Ana Meikle for her advice on the interpretation of the oestradiol results.

\section{References}

Blache D, Tellam RL, Chagas LM, Blackberry MA, Vercoe PE \& Martin GB 2000 Level of nutrition affects leptin concentrations in plasma and cerebrospinal fluid in sheep. Journal of Endocrinology 165 625-637. (doi:10.1677/joe.0.1650625)

Breier BH, Gallaher BW \& Gluckman PD 1991 Radioimmunoassay for insulinlike growth factor-1: solutions to some potential problems and pitfalls. Journal of Endocrinology 128 347-357. (doi:10.1677/joe.0.1280347)

CSIRO 2007 Nutrient requirements of domesticated ruminants. Victoria, Australia: CSIRO Publishing.

Evans AC, Mossa F, Fair T, Lonergan P, Butler ST, Zielak-Steciwko AE, Smith GW, Jimenez-Krassel F, Folger JK, Ireland JL et al. 2010 Causes and consequences of the variation in the number of ovarian follicles in cattle. Society of Reproduction and Fertility Supplement 67 421-429.

Ferguson MB, Thompson AN, Gordon DJ, Hyder MW, Kearney GA, Oldham CM \& Paganoni BL 2011 The wool production and reproduction of Merino ewes can be predicted from changes in liveweight during pregnancy and lactation. Animal Reproduction Science 51 763-775. (doi:10.1071/AN10158)

Fierro S, Olivera-Muzante J, Gil J \& Viñoles C 2011 Effects of prostaglandin administration on ovarian follicular dynamics, conception, prolificacy, and fecundity in sheep. Theriogenology 76 630-639. (doi:10.1016/ j.theriogenology.2011.03.016)

Gherardi PB \& Lindsay DR 1982 Response of ewes to lupin supplementation at different times of the breeding season. Australian Journal of Experimental Agriculture 22 264-267. (doi:10.1071/EA9820264)

Gluckman PD, Johnson-Barrett JJ, Butler JH, Edgar BW \& Gunn TR 1983 Studies on insulin-like growth factor-I and -II by specific radioligand assays in umbilical cord blood. Clinical Endocrinology 19 405-413. (doi:10.1111/j.1365-2265.1983.tb00014.x)

Gray CA, Bartol FF, Taylor KM, Wiley AA, Ramsey WS, Ott TL, Bazer FW \& Spencer TE 2000 Ovine uterine gland knock-out model: effects of gland ablation on the oestrus cycle. Biology of Reproduction 62 448-456. (doi:10.1095/biolreprod62.2.448)

Gunn RG, Sim DA \& Hunter EA 1995 Effects of nutrition in utero and in early life on the subsequent lifetime reproductive performance of Scottish Blackface ewes in two management systems. Animal Science $\mathbf{6 0}$ 223-230. (doi:10.1017/S1357729800008389)

Kleemann DO \& Walker SK 2005 Fertility in South Australian commercial Merino flocks: sources of reproductive wastage. Theriogenology 63 2075-2088. (doi:10.1016/j.theriogenology.2004.06.017)

Leury BJ, Murray PJ \& Rowe JB 1990 Effect of nutrition on the response in ovulation rate in Merino ewes following short-term lupin supplementation and insulin administration. Australian Journal of Agricultural Research 41 751-759. (doi:10.1071/AR9900751)

Littell RC, Pendergast J \& Natarajan R 2000 Modelling covariance structure in the analysis of repeated measures data. Statistics in Medicine $\mathbf{1 9}$ 1793-1819. (doi:10.1002/1097-0258(20000715)19:13<1793::AIDSIM482 > 3.0.CO;2-Q)

Marie M, Findlay PA, Thomas L \& Adam CL 2001 Daily patterns of plasma leptin in sheep: effects of photoperiod and food intake. Journal of Endocrinology 170 277-286. (doi:10.1677/joe.0.1700277)

Martin GB, Tjondronegoro S \& Blackberry MA 1994 Effects of nutrition on testicular size and the concentrations of gonadotrophins, testosterone and inhibin in plasma of mature male sheep. Journal of Reproduction and Fertility 101 121-128. (doi:10.1530/jrf.0.1010121)

McNatty KP, Hudson N, Henderson KM, Lun S, Heath DA, Gibb M, Ball K, McDiarmid JM \& Thurley DC 1984 Changes in gonadotrophin secretion and ovarian antral follicular activity in seasonally breeding sheep throughout the year. Journal of Reproduction and Fertility 70 309-321. (doi:10.1530/jrf.0.0700309) 
McNatty KP, Hudson N, Gibb M, Ball K, Henderson KM, Heath DA, Lun S \& Kieboom LE 1985 FSH influences follicle viability, oestradiol biosynthesis and ovulation rate in Romney ewes. Journal of Reproduction and Fertility 75 121-131. (doi:10.1530/jrf.0.0750121)

Miller DW, Blache D \& Martin GB 1995 The role of intracerebral insulin in the effect of nutrition on gonadotrophin secretion in mature male sheep. Journal of Endocrinology 147 321-329. (doi:10.1677/joe.0.1470321)

Nottle MB, Kleemann DO, Grosser TI \& Seamark RF 1997 Evaluation of a nutritional strategy to increase ovulation rate in merino ewes mated in late spring-early summer. Animal Reproduction Science 47 255-261. (doi:10.1016/S0378-4320(97)00025-0)

Rae MT, Palassio S, Kyle CE, Brooks AN, Lea RG, Miller DW \& Rhind SM 2001 Effect of maternal undernutrition during pregnancy on early ovarian development and subsequent follicular development in the sheep fetuses. Reproduction 122 915-922. (doi:10.1530/rep.0.1220915)

Rae MT, Kyle CE, Miller DW, Hammond AJ, Brooks AN \& Rhind SM 2002 The effects of undernutrition, in utero, on reproductive function in adult male and female sheep. Animal Reproduction Science 72 63-71. (doi:10.1016/S0378-4320(02)00068-4)

Rhind SM, Rae MT \& Brooks AN 2001 Effects of nutrition and environmental factors on the fetal programming of the reproductive axis. Reproduction 122 205-214. (doi:10.1530/rep.0.1220205)

Russel AJF, Doney JM \& Gunn RG 1969 Subjective assessment of body fat in live sheep. Journal of Agricultural Science 72 451-454. (doi:10.1017/ S0021859600024874)

Scaramuzzi RJ, Campbell BK, Downing JA, Kendall NR, Khalid M, MunozGutierrez M \& Somchit A 2006 A review of the effects of supplementary nutrition in the ewe on the concentrations of reproductive and metabolic hormones and the mechanisms that regulate folliculogenesis and ovulation rate. Reproduction, Nutrition, Development 46 339-354. (doi:10.1051/rnd:2006016)

Scaramuzzi RJ, Baird DT, Campbell BK, Driancourt MA, Dupont J, Fortune JE, Gilchrist RB, Martin GB, McNatty KP, McNeilly AS et al. 2011 Regulation of folliculogenesis and the determination of ovulation rate in ruminants. Reproduction, Fertility, and Development 23 444-467. (doi:10.1071/RD09161)

Sirois J \& Fortune JE 1990 Lengthening the bovine estrous cycle with low levels of exogenous progesterone: a model for studying ovarian follicular dominance. Endocrinology 127 916-925. (doi:10.1210/ endo-127-2-916)

Spicer LJ, Chamberlain CS \& Maciel SM 2002 Influence of gonadotropins on insulin and insulin-like growth factor-I (IGF-I)-induced steroid production by bovine granulosa cells. Domestic Animal Endocrinology 22 237-254. (doi:10.1016/S0739-7240(02)00125-X)

Tassell RJ, Kennedy JP, Bindon BM \& Piper LR 1983 Ovarian follicles of new-born Merino lambs from genetic lines which differ in fecundity. Australian Journal of Biological Sciences 36 351-355.

Teleni E, King WR, Rowe JB \& McDowell GH 1989 Lupins and energyyielding nutrients in ewes I. Glucose and acetate biokinetics and metabolic hormones in sheep fed a supplement of lupin grain. Australian Journal of Agricultural Research 40 913-924. (doi:10.1071/AR9890913)
Tindal JS, Knaggs GS, Hart IC \& Blake LA 1978 Release of growth hormone in lactating and non-lactating goats in relation to behaviour, stages of sleep, electroencephalograms, environmental stimuli and levels of prolactin, insulin, glucose and free fatty acids in the circulation. Journal of Endocrinology 76 333-346. (doi:10.1677/joe.0.0760333)

Viñoles C, Forsberg M, Banchero G \& Rubianes E 1999 Ovarian follicular dynamics and endocrine profiles in Polwarth ewes with high and low body condition. Animal Science 74 539-545.

Viñoles C, Forsberg M, Banchero G \& Rubianes E 2001 Effect of long-term and short-term progestagen treatment on follicular development and pregnancy rate in cyclic ewes. Theriogenology 55 993-1004. (doi:10.1016/S0093-691X(01)00460-5)

Viñoles C, Meikle A \& Forsberg M 2004 Accuracy of evaluation of ovarian structures by transrectal ultrasonography in ewes. Animal Reproduction Science 80 69-79. (doi:10.1016/S0378-4320(03)00141-6)

Viñoles C, Forsberg M, Martin GB, Cajarville C, Repetto J \& Meikle A 2005 Short-term nutritional supplementation of ewes in low body condition affects follicle development due to an increase in glucose and metabolic hormones. Reproduction 129 299-309. (doi:10.1530/rep.1.00536)

Viñoles C, Meikle A \& Martin GB 2009 Short-term nutritional treatments grazing legumes or feeding concentrates increase prolificacy in Corriedale ewes. Animal Reproduction Science 113 82-92. (doi:10.1016/ j.anireprosci.2008.05.079)

Viñoles C, Gonzalez de Bulnes A, Martin GB, Sales F \& Sale S 2010a In Chapter 11. Atlas of Ruminant and Camelid Reproductive Ultrasonography, pp 181-210. Eds Luc DesCôteaux, Jill Colloton \& Giovanni Gnemi. Ames, lowa, USA: Wiley-Blackwell.

Viñoles C, Paganoni B, Glover KMM, Milton JTB, Blache D, Blackberry MA \& Martin GB $2010 b$ The use of a 'first wave' model to study the effect of nutrition on ovarian follicular dynamics and ovulation rate in the female sheep. Reproduction 140 865-874. (doi:10.1530/REP-10-0196)

Viñoles C, Glover KMM, Paganoni BL, Milton JTB \& Martin GB 2012 Embryo losses in sheep during short-term nutritional supplementation. Reproduction, Fertility, and Development 24 1040-1047. (doi:10.1071/ RD11281)

White CL, Staines VE \& Staines MvH 2007 A review of the nutritional value of lupins for dairy cows. Australian Journal of Agricultural Research $\mathbf{5 8}$ 185-202.

Young JM, Thompson AN, Oldham CM \& Curnow M 2011 Whole-farm profit and the optimum maternal liveweight profile of Merino ewe flocks lambing in winter and spring are influenced by the effects of ewe nutrition on the progeny's survival and lifetime wool production. Animal Reproduction Science 51 821-833. (doi:10.1071/AN10078)

Received 14 March 2013

First decision 8 April 2013

Revised manuscript received 17 October 2013

Accepted 23 October 2013 